\title{
Deniss Kretalovs
}

Tieslietu ministrija, Sabiedrības integrācijas lietu departaments, Latvija

\section{RELIĢISKĀS KUSTĪBAS „JAUNĀ PAAUDZE" POLITISKĀS IDEOLOĢIJAS GALVENIE ASPEKTI}

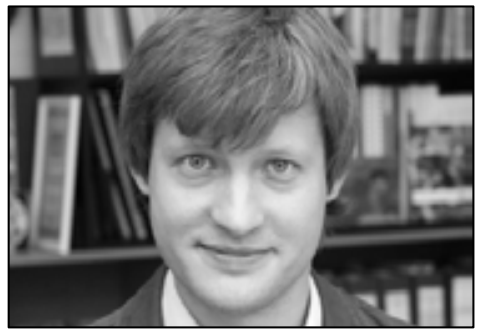

Rakstā aplūkota religiskās kustības „Jaunā paaudze" darbība un proponēto ideju sistēma, fokusējot uzmanību uz tās politiskās līdzdalības veidiem un orientieriem. Tādējādi tiek identificēti religiskās kustības politiskās ideologijas galvenie aspekti, kas veido tās politisko rīcību un attīstības vadlīnijas, kā arī nosaka tas sociālās un politiskās mobilitātes pakāpi.

Tādi faktori kā komunikācijas tīklu veidošanā iesaistītie sociālie aǵenti, diskursīvas telpas konstruēšanai izmantojamā izteiksmes retorika, ideju kopuma saturs, kas atspogulsojas organizācijas kontekstā lietotajos naratīvos, politikas stratēégiskās attīstības plānošanas modeļi un politiskie lozungi ḷauj identificēt „,Jauno paaudzi” $k \bar{a}$ uz kristīgo fundamentālismu orientētu religisku kustību, kas savu ideologiju konstruē pēc labējo kristiešu politiskajām tehnologijām un rīcības modelliem. Organizāaijas izvirzītā politiskā ideologija satur kristiešu rekonstrukcionisma ideologijas pazìmes - politiskas programmas un stratēgijas. Šajā ziņā „Jaunā paaudze” ir viena no tām kristīgā fundamentālisma organizācijām, kas piekopj radikālu un skaidri mērksētu politikas virzību.

\section{BASIC ASPECTS OF THE POLITICAL IDEOLOGY OF THE RELIGIOUS MOVEMENT ,NEW GENERATION”}

The subject of the article - the religious organization "New Generation" - is discussed as a new religious movement, and in the aspect of sociology of religion is to be typologically interpreted as a Christian neo-charismatic evangelical movement having formed as a result of cleavage. Attention is focused on the ways of political collaboration of the movement "New Generation" and the fundamental aspects of its political ideology.

The choice of the study subject is grounded on the lengthy and active activity of the group in the territory of Latvia, its topicality, popularity and dynamic growth in the material as well as in the social and political aspects. It is proved by several indicators of social attention and identification - the number of publications in press, intensity of thematic discussions and forums on the Internet, publicity measures, TV broadcasts, political and public activities.

The aim of the paper is to identify the main aspects of the political ideology of the religious organization "New Generation" by analyzing the available sources. In order to clear up these aspects, it is necessary to view the courses of activity of the religious organization and its activities in the spheres of civil, public and political participation.

As the reference objects, mass media materials have been used as well as periodicals featuring the discourse of the organization (interviews with the organization leaders). As the primary source, the book New World Order by Alexey Ledyaev, the founder and main leader of „New Generation”, has been used in which he voices the main postulates of his revelation as well as the political guidelines for the future development of the system of 
administration of the world and of Latvia. The book of A. Ledyaev is to be judged as the quintessence of the political ideology of ,New Generation" following which the social life in the congregation of this movement has been formed and ensured and which determines the degree of political participation and content of the movement adherents.

The following hypothesis is brought forward in the study - the elements and aspects forming the political ideology and the system of world-outlook and values of the religious movement "New Generation" clearly indicate a representation of the ideology of the Christian reconstructionism and its adaptation to the context and political situation of Latvia.

Factors like the social agents involved in the formation of communication networks, the rhetoric of expression used in the construction of the space for discourse, the content of ideas reflected in the narratives applied in the context of the organization, models of development planning of the strategic policy and political slogans allow identification of "New Generation" as a religious movement oriented to Christian fundamentalism, which construct its political ideology using the political technologies and action models of the rightist Christians. The political ideology realized by the organization contains features of Christian reconstructionism - political programmes and strategies. On this score, „New Generation" belongs to those Christian fundamentalist organizations that practise a radical and clearly targeted policy.

Šodien Latvijā demokrātisko vērtību un multikulturālisma izplatīšanās laikā vārda, reliğijas un sirdsapziņas brīvības principa īstenošanas kontekstā parādās un kḹūst arvien izteiksmīgākas dažādas reliğiskās kustības un organizācijas, veidojot un paplašinot vietējo reliğisko tirgu. Reliǵiskās daudzveidības laikmetā reliǵiskā piederība arvien vairāk kḷūst par grūti identificējamu un visai nosacītu sociālo elementu. Reliğiskajā tirgū notiek „cīṇa par patērētāju vairākuma piesaistīšanu” (Berger 1969: 137-138), reliǵisko organizāciju un kustību (denomināciju) piedāvājums ir visai plašs, un tās tiecas aptvert visas indivīda un sabiedrības vajadzības, cenšas piepildīt cilvēka dzīves ekspektācijas, piedāvā ikdienas realitātes pilnveidošanas veidus un nākotnes attīstības scenārijus (Krūmiņa-Koṇkova, Tēraudkalns 2007: 43). Politiskā līdzdalība ir viens no elementiem, kas raksturo lielu daḷu mūsdienu reliğisko organizāciju darbības un attīstības orientieru, to sekotāju un piederīgo tendenci pozicionēt sevi kā sociāli aktīvus indivīdus un politisku vadlīniju veidotājus.

„Jaunā paaudze” ir viena no reliǵiskajām organizācijām, kas pieteikusi sevi sabiedrībā un politikā kā aktīvs sociālais aǵents. Pêtījumā aplūkoti š̄s organizācijas ideoloǵijas pamataspekti, kas veido organizācijas politiskās līdzdalības vektorus, nosaka reliǵiskajā kopienā valdošo politisko diskursu un sociālo pozīciju.

Pētījuma mērķis ir identificēt relig̣iskās organizācijas „Jaunā paaudze” politiskās ideologijas pamataspektus, analizējot plašsazin̄ā pieejamos materiālus, periodiskos izdevumus, kā arī zinātniskos rakstus par jaunām reliğiskām kustībām, it īpaši par kristiešu pentakostu un evangéēliski harizmātiskām kustībām (Tēraudkalns 2007: 172-190). Kā 
pamatavots izmantots „Jaunās paaudzes” dibinātāja un galvenā līdera Alekseja L̦edjajeva (Алексей Ледяев) grāmata „Jaunā pasaules kārtība” („Новый мировой прядок”), kurā autors manifesta veidā pauž savas atklāsmes postulātus, vīzijas un attīstības principus, tostarp arī politiskās vadlīnijas pasaules un Latvijas sabiedrības nākotnei.

Pētniecības objekta izvēle ir pamatota ar šīs reliğiskās grupas ilgstošu un aktīvu darbību Latvijas teritorijā, tās aktualitāti, popularitāti un dinamisko attīstību kā materiālajā, tā arī sociālās un politiskās ietekmes ziṇā. To pierāda vairāki sociālās uzmanības un atpazīstamības rādītāji, piemēram, publikāciju skaits preses izdevumos, tematisko diskusiju un forumu intensitāte internetā, plaši reklamētas aktivitātes, kā arī sabiedriskie pasākumi, TV raidījumi, politiskas un publiskas aktivitātes.

Raksta autors apraksta jēdziena „politiskā ideoloǵija” lietojumu, sniedz reliğiskās organizācijas „Jaunā paaudze” darbības īsu raksturojumu un ieskatu labējo kristiešu nostādnēs politikas diskursā, kā arī identificē un analizē "Jaunā paaudzes" ideologijas galvenos aspektus.

\section{Politiskās ideologijas jēdziens}

Šī raksta kontekstā ar jēdzienu ,politiskā ideolog̣ija” tiek saprasta pārliecību un uzskatu sistēma, kas atspoguḷo sociāli politisku realitāti, ņemot vērā dominējošo sabiedrisko grupu intereses (Шевченко 2001: 199). Politiskā ideologija lielākoties nosaka un leǵitimizē politisko reformu programmas, nākotnes attīstības vadlīnijas, politisku stratēgiju un politisku prioritāšu jautājumu kopu. Maks Vēbers (Max Webber) uzskata ideolog̣iju par līdzīgu citiem reliǵiozajiem un pārliecības veidojumiem, par ticības sfêras fenomenu (pretstatā zinātnes sfērai), par neadekvātu realitātes atspoguḷojumu, kura funkcija ir veicināt sabiedrības integrāciju, orientējot un strukturējot tās pārstāvjus dažādos sociālajos līmeņos (Пугачев; Соловьев 2000: 254-270). Aplūkojot mūsdienu politiskajā zinātnē pastāvošo skaidrojumu par ideoloǵijas nozīmi, jāsecina, ka tās galvenā funkcija ir ietekmēt sabiedrības domu tādā veidā, lai sadrumstaloto sabiedrības masu vienotu kolektīvā apziņā nosprausto mērķu un uzdevumu atpazīšanai politiskajā diskursā (Гаджиев 1999). Konstruējot politisko diskursu, notiek konkrētas ideoloǵiskas sistēmas ieviešana sociālajā un politiskajā telpā. Citu ideologiijas konstruējošo aparātu starpā ir reliǵiskās organizācijas, kas reflektē noteiktu sociālo grupu vai kopienu interesēs, attiecinot tās uz visu sabiedrību. Kā ideoloǵijas pamatelementi jāidentificē politiskās vadlīnijas, politiskās elites veidotas ekspektāciju zīmes, kas stimulē sabiedrības politisko rīcību un līdzdalību. Tādējādi, analizējot konkrētas reliğiskas organizācijas vai kustības ideologiijas struktūras 
un diskursu, ir iespējams noteikt šīs organizācijas attīstības trajektorijas sociālajā un politiskajā telpā.

\section{Reliğiskās organizācijas „Jaunā paaudze” raksturojums}

Turpmāk tiks ieskicēta draudzes "Jaunā paaudze" vēsture un attīstība, neiedziļinoties tās mācības un teologijijas skaidrošanā, kā arī organizācijas sociālā tîklojuma un struktūru noteikšanā. „Jaunā paaudze” tiks aplūkota kā jauna reliǵiskā kustība ${ }^{1}$ un tipolog̣iski interpretēta reliğijas sociolog̣ijas aspektā kā kristīga neoharizmātiska evaņgéeliska kustība ar pentakostisma elementiem (Tēraudkalns 2007: 172-190).

Reliğisko organizāciju „Jaunā paaudze” 1989. gada novembrī dibina bijušais Rīgas Vasarsvētku baznīcas vadītājs, toreiz baptists pēc pārliecības ${ }^{2}$ Aleksejs Ḷedjajevs, kad tiek atbrīvots no mācītāja amata bīskapa Vasilija Boečko (Василий Боечко) vadītajā Vasarsvētku baznīcā. Atlaišanas iemesls ir šķelšanās starp Rīgas Vasarsvētku baznīcas mācītājiem. V. Boečko pārmet A. Ļedjajevam viņa dievkalpojumu jaunievedumus - izrādes elementus un modernas mūzikas pavadījumu, emocionāli ekspresīvo un brīžiem agresīvo sludināšanas manieri u. c. jauninājumus, kas ir nepieņemami tradicionālajai Vasarsvētku konfesijai un tamdēḷ izraisa asu kritiku. ${ }^{3}$

Atmodas atmosfēra, kas valdīja sabiedrībā 90. gadu sākumā, stiprina A. Ļedjajeva ieceres piesaistīt savu ideju īstenošanai dedzīgus piekritējus, ar kuriem varētu dibināt jaunu draudzi (Шабанов 1995). ${ }^{4}$ Uz jaunradi tendētais A. Ļedjajevs, rīkojot vairākas aǵitācijas akcijas un aktīvi propagandējot ,jauno” Dzīvā Dieva pielūgsmi, visai īsā laika posmā sapulcina aptuveni 150 atbalstîtāju. Rezultātā jau 1991. gada jūlijā draudze tiek reǵistrēta Latvijas Republikas Tieslietu ministrijas relig̣isko organizāciju reǵistrā kā Evaņgê̄liskās ticības kristiešu baznīca „Jaunā paaudze” (29.07.1991. Nr.710).

\footnotetext{
${ }^{1}$ Jauno reliǵisko kustību apzīmējumā religiju pētnieki bieži vien sintezē dažāda rakstura reliǵiskās grupas, apvien̄ibas, kustības, garīgas attīstības mācību sistēmas un reliǵiskās prakses, kas ir nesen parādījušās reliǵiskajā tirgū kādas konkrētas sabiedrības kontekstā (Barker 2001: 10631-10634; Krūmiņa-Koṇkova, Tēraudkalns 2007; Chryssides 1997).

${ }^{2}$ Fragments no A. LLedjajeva intervijas „Новости христианского мира”: „Mе̄s esam baptisti. Bet baptistu baznīcā pirms 20-30 gadiem vispār neviens par labklājību nebija mācījis (Сf. Ледяев рассказывает 2006).

${ }^{3}$ Fragments no A. L,edjajeva intervijas: „Mēs bijām atmetuši cilvēku uzliktos likumus, piemēram, to, ka sievietes nedrīkst lietot kosmētiku, ka, Dievu lūdzot, viṇām galvā jāsien lakatiṇš, ka, mūzikai skanot, nekādā ziņā nedrīkst lūgt Dievu, un tā es šos aizliegumus varētu vēl turpināt. Es zināju, ka Dievs mūs dzird arī bez visiem šiem noteikumiem, bet tā bija sacelšanās pret tā laika tradīijāàm. Draudze bija sadalījusies divās savā starpā karojošās nometnēs." (Сf. Ледяев рассказывает 2006)

${ }^{4}$ A. Šabanovs apgalvo, ka 1991. gada 11. maijā ar zviedru Vasarsvētku draudzes pārstāvju (U. Ekmana, P. Igrena) atbalstu A. L̦edjajevs mēǵina reǵistrēt savu draudzi Tieslietu ministrijas (turpmāk - TM) reǵistrā kā garīgi izglītojošo centru „Jaunā paaudze”, bet saņem atteikumu. 1992. gadā viņ̌̌ atkārtoti iesniedz prasību registrēt centru, bet TM paziņo, ka pēc sludinātās reliğiskās mācības u. c. pazīmēm draudzi iespējams reǵistrēt tikai kā Vasarsvētku draudzi „Jaunā paaudze”. Bet A. Šabanova rakstā minēts, ka draudzes „Jaunā paaudze" oficiālais reǵistrācijas numurs izdots 1991. gadā 29. jūlijā (Шабанов 1995).
} 
Pastāvēšanas sākumposmā draudzi būtiski atbalsta Vasarsvētku evaņǵelizācijas krist̄̄gais centrs „Dzīvības vārds” (Livets Ord) Ulafa Ekmana (Ulf Gunnar Ekman) un Karla Gustava Severina (Carl Gustaf Severin) vadībā. ${ }^{5}$ Organizācija „Dzīvības vārds” tajā laikā ir viena no spēcīgākajām kristīgi neoharizmātiskajām kustībām Zviedrijā, kuru sabiedriskajā telpā bieži vien vērtē kā smadzeņu skalošanas, naudas piesavināšanas, bīstami labēji noskaņotu, amerikanizētu un nezviedrisku organizāciju (Coleman 2000: 9). ${ }^{6}$ Organizācijai strauji attīstoties, tās darbība sāk sniegties krietni pāri Skandināvijas valstu robežām, aktīvi veidojot sadarbības kontaktus ar jaunām reliǵiskām formācijām gan Rietumeiropā, gan bijušajās PSRS republikās, tostarp Baltijas valstīs. Tieši organizācijas „Dzīvības vārds” vadītāji, saskatot A. Ĺedjajevā organizatora un līdera potenciālu, piedāvā viņam ar draudzi pārstāvēt Latviju „Dzīvības vārda” starptautiskajā tīklā.

Pakāpeniski intensificējot savas darbības tempus, ambiciozais A. L̨edjajevs izvēlas iet vēl radikālāku ceḷu nekā viṇa Skandināvijas partneri. Pēc viṇa manifesta „Jaunā pasaules kārtība” publicēšanas 2002. gadā zviedru evanggelizācijas kristīgā centra „Dzīvības vārds” aktīvisti un vairāki „Jaunās paaudzes” locekḷi pārtrauc attiecības ar A. L̦edjajevu. Šajā attīstības posmā draudzē notiek pakāpeniska pārorientācija uz viṇa ,jaunās pasaules kārtības” ieviešanu Latvijā un citās valstīs. Mainās arī draudzes vadošās elites sadarbības partneri un organizācijas struktūra, paaugstinās tās sabiedriskās līdzdalības līmenis un paplašinās ārējo sociālo komunikāciju intensitāte. A. Ļedjajeva izvēēētā draudzes attīstības vīzija pārsātināta ar asu „cīnītāja” retoriku par labu konservatīvo kristiešu ideju un vērtību aizstāvēěanai.

Globalizācijas procesu ietekmē notiekošo iekšējo pārmaiņu rezultātā no 1989. gada līdz 2009. gadam draudze izaug par starptautisku reliǵisku kustību ar vairāku filiālu transnacionālo tīklu visā pasaulē. ${ }^{7}$ Statistikas dati par Latvijas Republikā reǵistrēto konfesiju draudzēm un draudžu locekḷiem liecina, ka uz 2005. gada 1. janvāri organizācijā ir reǵistrētas 15 draudzes un 5170 locekḷi (Latvijas Reliğiskās organizācijas 2005: 6), bet

\footnotetext{
${ }^{5}$ Fragments no U. Ekmana un A. L̦edjajeva sarunas stenogrammas 2003. gada 18. decembrī. A. L̦edjajevs: Es vispār cienu jūs kā Dieva kalpus un mūsu skolotājus... Jūs taču no sākuma mācījāt lūgties, kliegt, karot. [..] U. Ekmans:[..] un ja tu dari to, ko mēs bijām mācījuši [..], tad mēs arīdzan bijām mācījuši tevi klausīties un būt paklausīgam. (Cf. Официальная позиция 2004)

${ }^{6}$ Vairāk par reliǵisko organizāciju „Dzīivības vārds” skatīt (Coleman 2000).

7 2006. gadā ,Jaunās paaudzes” kristīgie centri (New Generation Christian Centers) atrodas 16 pasaules valstīs: Latvijā, Argentīnā, Armēnijā, Baltkrievijā, Krievijā (45 centri), Ukrainā (119 centri), Polijā, Igaunijā, Somijā, Lielbritānijā, ASV, Lietuvā, Izraēlā, Vācijā, Kazahstānā, Uzbekistānā (Cf. Официальная позиция 2004; Cf. New Generation Christian Center (skatīts 16.01.2009.)).
} 
uz 2008. gada 1. janvāri - 5075 locekḷi (Reliğisko savienību (baznīcu), diecēžu un religisisko organizāciju 2008. gada pārskats: 5$){ }^{8}$

Organizācijas mājas lapā norādīts, ka 2009. gadā tās darbības misija ir „,nostiprināt Dieva Valstību visās mūsu dzīves sfērās, tai skaitā medijos, kultūrā, politikā, izglīīībā, biznesā u. c. „Jaunā paaudze” cieši sadarbojas ar citu baznīcu vadītājiem un politiskajiem līderiem, kuri apzinās Lielā Uzdevuma svarīgumu." (Cf. Baznīca (skatīts 15.12.2008.)) Šis raksturojums reprezentē organizācijas politikās ambīcijas - valsts varas institucionālā aparāta pakāpenisku pārorientēšanu uz kristīgajām vērtībām un visas sabiedrības evaņgelizāciju. Komunikāciju loka un sociālo tīklu paplašināšana starptautiskajā mērogā, partnerattiecību veidošana ar konkrētiem politiskās elites pārstāvjiem, tieksme uz dialogu ar citu kristīgo konfesiju pārstāvjiem kop̄̄gu mērḳu sasniegšanai ir tie instrumenti, kurus organizācija izmanto, lai izpildītu šo politisko misiju.

Līdzīgi pārējām neoharizmātiskajām draudzēm, „Jaunā paaudze” jau no paša sākuma orientējās uz vidusšķ̧iras mērķauditoriju, pārsvarā jauniešiem un vecāka gadagājuma cilvēkiem. Daudzveid̄̄gi un radoši pielietojot dievkalpojumos jaunas tehnologijas, mūsdien̄̄gu mūziku un dejas, masu komunikācijas līdzekḷus, PR kampaṇas, draudze piedāvā dievkalpojuma formu kā atraktīvu un teatrālu uzvedumu jeb masu konferenci. ${ }^{9}$ Tas piesaista draudzei energiskus un apņēmīgus sabiedrības pārstāvjus, kuri iekḷaujas religískās kopienas hierarhijas veidošanā un struktūras paplašināšanā.

Balstoties uz Starka-Beinbridža (Rodney Stark, William Bainbridge) relig̣ijas sociolog̣ijas trīspakāpju dalījumu baznīca-sekta-kults, kustība „Jaunā paaudze” ir jāidentificē kā sektas tipa reliǵiska organizācija. Uz piederību šim tipam norāda draudzes dibināšanas vēsture - tā izveidota šķelšanās jeb shizmas ${ }^{10}$ rezultātā, atdaloties no lielākas reliğiskas struktūras (Stark, Bainbridge 1985: 25). Rodnijs Starks un Viljams Beinbridžs sektu raksturo kā reliǵisku kustību ar organizētu grupas veida struktūru, kas tiecas kḷūt par pilnvērtīgu, atzītu un leǵitīmu reliǵijas institūtu, izvēloties „lielās spriedzes” (tension) trajektoriju (Stark, Bainbridge 1985: 23-24). „Jaunās paaudzes” pašidentifikācijas process ilustrē, kā relig̣iska organizācija, kas sākumā pretendē uz sektas statusu, savā attīstības

\footnotetext{
${ }^{8}$ Oficiālais draudzes locekḷu skaits jāuztver skeptiski. Reliǵisko lietu pārvaldes pārskatā par 2008. gadu norādīts tieši tāds pats regíistrēto sekotāju skaits kā 2005. gadā un 2006. gadā. Tie ir dati, ko sniedz pati organizācija, un tie ir grūti pārbaudāmi. Tas pats attiecas arī uz draudžu skaitu.

${ }^{9}$ Viens no „Jaunās paaudzes” garīgās konferences pastāvīgajiem viesiem, Nigērijas harizmātiskās draudzes mācītājis Anselms Madubuko, raksturo minēto orientāciju šādi: „Kristietībai ir jāizmanto paši modernākie garīgie ieroči cīņai ar sātanu. [..] Šodien neviena armija nelieto novecojušo aprīkojumu. Tāpat arī baznīcai ir jāaug lūgšanā, jāpāriet jaunā svaidīšanas un spēka līmen̄i, nesamierinoties ar vecām atklāsmēm un nesadzīvojot ar vecām, vienveidīgām lūgšanām.” (Tēraudkalns 2007: 177)

${ }^{10} \sigma \chi i ́ \sigma \mu \alpha$ - „šķelšanās”, ,atsacīšanās”, „strīds” kristīgo baznīcu kontekstā. Shizma (gr. schisma) nodalīšanās no likumīgā bīskapa [škseltniecība - D. K.] (Cf. Baznīcas terminu vārdnīca (skatīts 16.01.2009.)).
} 
dinamikā universalizējas, tiecoties pārtapt par baznīcu un pat denomināciju/konfesiju (Stark, Bainbridge 1985: 22). „Jaunā paaudze”, pakāpeniski attīstoties, pastāvīgi piemēro sev jaunu identitāti: 20. gadsimta 90. gados tā dēvē sevi par kristīgās izglīî̄bas centru, 21. gadsimta sākumā identificē sevi ar kristīgo baznīcu, neuzsverot savu konfesionālo piederību konkrētai Vasarsvētku grupai jeb pentakostiem, pēdējos gados (2007-2009) sastopami vairāki pašas organizācijas sniegtie apzīmējumi - „starptautiskā apustuliskā kustība” (Cf. Baznīca (skatīts 15.12.2008.)) un „religiskā konfesija kā piecdesmitnieku harizmātiskā kustība”. (Cf. Времена меняются 2008) Vērojot „Jaunās paaudzes” attīstības dinamiku, no vienas puses, centieni veidot dialogu ar citu kristiešu konfesiju līderiem un atsevišķiem politiskās elites pārstāvjiem norāda uz organizācijas tieksmi mazināt spriedzi (tension) ar varas eliti, no otras puses - agresīvā aǵitācija un neiecietība pret atsevišķām minoritāšu grupām liecina par tās konfrontācijas palielināšanos publiskajā telpā.

Apzīmējums ,sekta” mūsdienu sabiedrībā ir visai politizēts un bieži vien tiek izmantots, lai diskreditētu, apvainotu vai ciniski raksturotu kādu reliǵisku minoritāti, uzsverot tās atšķirību no tradicionālo relig̣iju konfesijām vai izceḷot tās „citādību” un „svešo dabu”. Organizācijas „Jaunā paaudze” piederība „sektai” ir nostiprinājusies sabiedriskajā diskursā, n̦emot vērā: 1) organizācijas vadītāja patosu, nosaucot sevi par Dieva apustuli; 2) netradicionālo kristīgo vērtību sludināšanas un dievkalpojuma pieeju (Tēraudkalns 2007: 175-183); 3) reliğiskās organizācijas orientāciju uz materiālo labklājību; 4) organizācijas galvenā mācītāja un citu līderu agresīvo un neiecietīgo attieksmi pret netradicionālajām minoritātēm.

\section{Ieskats kristiešu labējo kustību politiskajās ideologiijās}

Mūsdienu globalizācijas un transnacionālo tīklu attīstības laikmetā ir visai komplicēti noteikt tās pamatiezīmes un raksturojošos elementus, kas attiecināmi uz visām Vasarsvētku neoharismātiskajām kustībām. It īpaši tas saistīts ar centieniem identificēt šo kristietības virzienu politisko pozīciju un to politiskās ideologijas saturu, kurā mēdz saskatīt pat kardināli pretējus uzskatus, piemēram, liberāli noskaņotos sociālistus un reizē konservatorus ar galēji labējām nostādnēm (Tēraudkalns 2007: 176). Pētnieks Frederiks Andersons (Frederick Anderson), kas aplūko pentakostismu kā globālu sociālu fenomenu, šo vērtējumu daudzveidību izskaidro ar to, ka Vasarsvētku kustības sākums un attīstība nav saistāma ar kādu konkrētu personību un draudzi, bet ar atsevišķu līderu aktīvu reliǵisku darbību 20. gadsimtā dažādās pasaules daḷās (Anderson 2004: 172). 
Pēdējos 30 gados novērots, ka liela dạ̧a no Vasarsvētku neoharismātiskajām draudzēm aktīvi iesaistās politikā, pārsvarā atbalstot konservatīvi labējo spārnu. Šī tendence visvairāk pamanāma ASV, bet arī ārpus tās aizvien vairāk neoharismātu kustîbu kḷūst politiski aktīvas, iestājoties par labējo idejām.

Labējo kristiešu ${ }^{11}$ politiskie lozungi aicina uz kristīgo vērtību saglabāšanu, propagandējot konservatīvās idejas Amerikas stabilas un ètiski skaidras nākotnes nodrošināšanai, kritizējot kreisi orientēto liberāḷu dienas kārtības jautājumus, piemēram, dzimumu līdztiesību un iecietības politiku pret cilvēkiem ar dažādu seksuālo orientāciju, reliğijas pārliecību un etnisko izcelsmi.

Kopš 80. gadiem labējie kristieši ieņem visai spēcīgu pozīciju ASV politiskajā arēnā. 1979. gadā pēc teleevaņgélista Džerija Felvuela (Jerry Falwell) ierosinājuma izveidota organizācija "Morāla majoritāte" (Moral Majority), ${ }^{12}$ kura, iestājoties par paraugǵimeṇu un Paraugamerikas attīstību, kḹūst par kristiešu fundamentālistu ideju katalizatoru. Bet par ievērojamu politisku spēku labējie kristieši pārvēršas 1980. gadā, kad ar viņu atbalstu ASV prezidenta vēelěšanās uzvar Ronalds Reigans (Ronald Reigan). Savu politisko ietekmi labējie ar Petu Robertsonu (Pat Robertson) priekšgalā uz brīdi izlaiž no rokām tikai 1988. gadā, zaudējot cīnā par prezidenta krēslu. Tomēr jau 1994. gadā labējie revanšējas - Republikāṇu partija Džordža Buša (George Bush) vadībā uzvar ASV prezidenta vēlēšanās (Hicks 1996-2003). Dž. Buša prezidenta kampaņu vada labējā spārna līderis P. Robertsons. 2003. gadā aptuveni 15\% no ASV elektorāta identificē sevi ar labējiem kristiešiem, kas ir nopietns vēlētāju bloks Republikāṇu partijā. Pēc amerikāṇu reliğijas filozofa Džona Hiksa (John Hicks) domām, neskatoties uz to, ka labējiem kristiešiem ir pietiekami noturīgi komunikācijas un sociālie tīkli, lai ietekmētu elektorāta politiķus un politisko lēmumu pieņemšanu, ASV politiskajā sfērā tiem trūkst vienotības potenciāla (Hicks 1996-2003).

Kristiešu labējo kustību attīstība cieši saistīta ar tās fleksibilitāti un spēju savlaicīgi mainīt darbības stratēgijiju atbilstoši politiskā un publiskā diskursa aktuālajiem jautājumiem.

\footnotetext{
${ }^{11}$ Labējie kristieši (Christian Right) ir aktīva, politiski ievirzīta kustība, kas ietver sevī indivīdus ar dažādiem teolog̣iskiem uzskatiem un ticības pārliecības pakāpi, piemēram, luterāņus, pentakostus, kristiešu fundamentālistus un mormoņus. Bieži vien labējos kristiešus dēvē arī par reliǵiski labējiem, kas ir neadekvāts apzīmējums, jo par reliǵiski labējiem var būt ikviena reliğiska tradīcija vai kustība, piemēram, musulmaņi vai ebreji (Murray 1996; Wilcox 1996).

${ }^{12}$ Sabiedriskā organizācija "Morāla majoritāte" (Moral Majority) iestājas pret tādām sociālām kustībām, kas aizstāv aborta legalizāciju, cīnās par geju un sieviešu tiesībām. Tā aizstāv lūgšanu ieviešanu izglītîbas iestādēs, aizsardzības politikas stiprināšanu. Tieši šī organizācija kḷūst par jauno kristiešu fundamentālistu ideju katalizatoru un to ienākšanu politiskajā arēnā. Organizācija piesaista piekritējus, proponējot idejas par paraugǵimeni un Paraugameriku (Cf. The Moral Majority (skatits 16.01.2009.)).
} 
Piemēram, pēc savas sakāves P. Robertsons nomaina politiskos saukḷus elektorāta mobilizēšanai, akcentējot ǵimenes, kristiešu pamatvērtību saglabāšanu globalizācijas kontekstā. Pēdējā laikā manāma labējo tieksme iesaistīt politiskajā kampaṇā arī citu konfesiju un relig̣iju pārstāvjus - katoḷus, ortodoksālos jūdaistus u. c., lai vienoti cīnītos par kopējiem mērķiem, vai drīzāk - pret kopējiem ienaidniekiem.

Nav pārsteigums, ka neoharismātiskajām kristīgajām kustībām labējo kristiešu proponētās idejas par teokrātisku valdību un politisko varu ir tik pievilcīgas. Tāpat kā labējie kristieši, neoharismāti savas politiski ideologiskās stratēǵijas veido, strikti ierāmējot tās pretstatā „mēs - viṇi”, kur ar pretpolu „viṇi” tiek saprasts tāds „ienaidnieks”, kas apdraud kristiešu primāro lomu sabiedrības veidošanā un noraida kristīgo vērtību dominanti. Apliecinājums tam ir Vasarsvētku neoharismātu kustību pārstāvju atbalsts P. Robertsonam 1988. gada vēlēšanu kampaņā (Hicks 1996-2003).

Amerikāṇu žurnālists un publicists Frederiks Klarksons (Frederick Clarkson), kurš pēta reliğisko grupu labējo spārnu, īpašu uzman̄̄bu pievērš kristiešu fundamentālistu politiskās ideoloǵijas formai - kristiešu rekonstrukcionismam, kā arī tām reliǵiskajām grupām, kas izmanto šo ideologiju savu politisko programmu veidošanā (Clarkson 1994). Kristiešu rekonstrukcionisma virziena ${ }^{13}$ ideju pamatā ir tieksme aizstāt demokrātisku pārvaldes sistēmu ar teokrātiski noskaņotu politisko eliti, kas savā darbībā vadītos pēc „Bībeles likuma” (Biblical Law), pielāgojot to atbilstoši situācijai. Rekonstrukcionisma ideologijas piekritēji uzskata kristiešu morālos principus un vērtību sistēmu par absolūto uzvedības kodeksu un strikti noraida jebkādas izpausmes, kas ir pretrunā ar to, kā, piemēram, ķecerība, aborti, homoseksualitāte, pornogrāfija, narkomānija (Clarkson 1994).

Savās politiskajās programmās kristiešu rekonstrukcionisti propagandē radikāli konservatîvas idejas, pamatojot tās tikai un vien̄̄gi ar Bībeles autoritāti. ${ }^{14}$ Pēc rekonstrukcionisma ideolog̣ijas principiem civilā iekārta kalpo kristiešu Dieva likumu ieviešanai visos pārvaldes līmeņos un hierarhijā. Augstākās varas institūtam ir jābalstās uz Dieva likumiem, tam jāpakḷauj ikviens pilsonis neatkarīgi no viṇa etniskās izcelsmes, dzimuma, sociālā stāvokḷa. Tos sabiedrības pārstāvjus, kas piekopj grēcīgu dz̄ives veidu (Bībeliskajā izpratnē), rekonstrukcionisti dēvē par valsts ienaidniekiem un pieprasa tiem

\footnotetext{
${ }^{13}$ Rekonstrukcionisma ideoloǵijas piekritēju koncepcijas pamatavots ir R. Dž. Rašdūnija (Rousas John Rushdoony) 1973. gadā publicētie Bībeliskā likuma institūti (Institutes of Biblical Law), kur 800 lappusēs skaidroti desmit baušșii. Pēc tiem - konstitūcijai obligāti ir jābalstās uz kristietību, nevis uz uzskatu, vārda brīvības un plurālisma principiem.

14 Viens no ideologijas pārstāvjiem Deivids Čiltons (David Chilton) šādi apraksta rekonstrukcionistu pamatmērķi: „Kristiešu mērķis pasaulē ir Bībeliskās teokrātiskās republikas vispārēja attīstība, kurā ikviena sfēra pakḷauta Jēzus Kristus Kunga un Dieva likumiem.” (Clarkson 1994)
} 
nāvessodu. Nāvessoda piemērošanas veids arī tiek attaisnots ar Svēto Rakstu autoritāti (nomētāšana ar akmeņiem, pakāršana, noduršana ar zobenu).

Rekonstrukcionisma ideju popularizēšanai aktīvi tiek izmantotas mūsdienu informācijas un masu komunikāciju tehnolog̣ijas. Viena no ietekmīgākajām labējo kristiešu fundamentālistu organizācijām šajā aspektā ir Kristiešu koalīcija (Christian Coalition) (Cf. Christian Coalition (skatîts 04.03.2009.)), ko 1988. gadā nodibina vēelěšanu kampaņu speciālists Pets Robertsons kopā ar Republikāṇu aktīvistu Ralfu Rīdu (Ralph Reed) prezidenta priekšvēlēšanu kompānijas atbalstam. Šīs organizācijas pamatfunkcija ir vēlētāju mobilizēšana un interešu lobēšana prezidenta Džordža Buša kompānijas laikā. Par Džordža Buša elektorāta sasniegumiem saistîbā ar „balto” evaņgélistu atbalstu vēlēšanās liecina statistika: 2000.gadā par Dž. Bušu nobalso 68\% „balto” evaņgèelistu, bet 2004 . gadā - 78\% (Linker 2008).

Kristiešu koalīcijas misijā ietilpst juridisku konsultāciju sniegšana īstenām kristiešu ǵimenēm (pro-family), šo ǵimeņu pārstāvniecība lokālajās padomēs, izglītības iestādēs, valsts pārvaldes institūcijās un Kongresā, kā arī kristiešu vērtību aktīva propaganda publiskajā sfērā, līderu sociāla un politiska apmācība un protestu akciju rīkošana pret antikristiešu manifestācijām. Organizācijas politiskajā diskursā skaidri konstruēti rekonstrukcionisma ideologijas pamatelementi: ienaidnieka tēla veidošana; Vispasaules kristiešu valdības dibināšanas ideja; proaktīva politiskā līdzdalība; radikāla, izteikti neiecietīga attieksme pret seksuālajām un ne-kristiešu reliğiskajām minoritātēm.

\section{Kustības „Jaunā paaudze” politiskās ideologiijas galvenie aspekti}

Kaut arī kustības „Jaunā paaudze” tieksme aktīvi iesaistīties politiskajos un sabiedriskajos procesos pilnvērtīgas labdarības organizācijas un visu kristiešu tiesību aizstāvētājas veidolā ļauj tai arvien biežāk parādīties sabiedriskajā diskursā, tomēr tās piekoptās kristiešu rekonstrukcionisma ideolog̣ijas dēḷ „Jaunajai paaudzei” ir sarežğîti iegūt pietiekami lielu atbalstītāju skaitu un ievērojami ietekmēt politiskās varas lēmumus. Cik lielā mērā ,Jaunā paaudze” Latvijā varētu sasniegt tos panākumus, ko uzrāda labējo kristiešu rekonstrukcionisti ASV?

Visbiežāk „Jauno paaudzi” sabiedriskajā un politiskajā diskursā reprezentē tās galvenais līderis Aleksejs L̦edjajevs. Viņa nostāja, autoritāte, paustais viedoklis lielākoties nosaka organizācijas idejisko virzību un darbības stratēǵiju. Būdams organizācijas „,seja”, A. Ľedjajevs savu sabiedrisko imidžu un pozīciju pārsvarā konstruē, uzņemoties aktīva eksperta lomu gadījumos, kad jāizsaka savs vērtējums politiķu rīcībai un pieņemtajiem 
lēmumiem. Viṇa izteiksmes līdzekḷu (sprediķis, svinīga uzruna, teatrālā uzveduma scenārijs, grāmatas, publiskie izteikumi, sniegtie komentāri un intervijas plašsaziņas līdzekḷos) analīze var sniegt pilnīgāku priekšstatu par kustības politiskās ideologijijas saturu.

Tie politiskie lozungi un priekšnosacījumi, ko A. L̦edjajevs izmanto publiskajā telpā vismaz pēdējos astoņos gados, atklāj viṇa ciešo saikni ar ASV kristiešu rekonstrukcionistiem. A. L̦edjajevs nosauc vairākas autoritātes, kas būtiski ietekmē „Jaunās paaudzes” attīstību un politiskās simpātijas, piemēram, Skots Laivlijs (Scott Lively), Kens Hatčersons (Ken Hutcherson), Pets Robertsons u. c.

„Jaunās paaudzes” politiskās vadlīnijas atrodamas A. Ľedjajeva 2002. gadā publicētajā manifestā „Jaunā pasaules kārtība”. Organizācijas oficiālajā mājas lapā šis sacerējums raksturots kā „,visslavenākais no mācītāja Alekseja darbiem, kas kḷūst par baznīcas „Jaunā paaudze” līdera filozofiskā brieduma liecību [..], iezīmējot pēdējā laika kalpošanas taktiku un stratēgiju. Pats baznīcas gars - harismātiskais, radikālais, reformējošais - nosaka mācītāja pozīciju un viṇa vīziju par kristiešu lomu un vietu mūsdienu pasaulē. Iejaukšanās un ekspansija - lūk, galvenā pēdējā laika baznīcas stratēgija [..], lūk, skrejcel̦š, pa kuru baznīca ies un sludinās Dieva Valstīibu pa visu pasauli.” (Cf. Grāmatas [skatīts 15.12.2008.]).

A. L̦edjajeva ideja par jaunās pasaules kārtības veidošanu visticamāk ir aizgūta no Kristiešu koalīcijas līdera Peta Robertsona 1991. gadā iznākušā sacerējuma „Jaunā pasaules kārtība" (The New World Order) (Robertson 1991). Robertsons savā grāmatā pauž radikālas idejas par vispasaules sazvērestību politiskajā un ekonomiskajā līmen̄i, vēršoties pret asociālajiem sabiedrības elementiem, piemēram, narkotiku tirgotājiem, alkohola lietotājiem, revolucionāri noskaņotajiem fanātiķiem, ka arī pret nekristiešu pārstāvjiem - sekulārajiem humānistiem, homoseksuāļiem, komunistiem, ateistiem, sātanistiem. Visas šīs sabiedrības grupas ar savu dzīves veidu un uzvedību atbalsta „,antikrista” sacelšanos pret kristiešu pasauli un tās vērtībām. Dons Viklejs (Don Wilkey) recenzijā par P. Robertsona grāmatu raksturo tās autora nostāju šādi: „Sātans stāv pie pasaules valdīšanas programmas [..], kas nozīmē ASV sabrukšanu, piepildot viņa [sātana D. K.] mērķus. Sātana interese par starptautisko naudu tiecas uz ārzemju politikas kontroli." (Wilkey 1991)

Līdzīgi P. Robertsonam A. L̦edjajevs savā manifestā izmanto konspirācijas teoriju, iezīmējot atpazīstamos ienaidnieku tipus, kas nostājas pret kristīgās ideologijas būtību, manipulē ar politiķiem un varas pārstāvjiem - okultisti, priesteri, masoni, astrologi, pareǵotāji, burvji, ekstrasensi un citi slepenie padomdevēji (Ледяев 2002: 11). 
Gluži kā rekonstrukcionistu nākotnes atklāsmes, arī A. L̦edjajeva radikālā vīzija par jauno kārtību izpaužas kā augstāko evanggeēlisko ideju ielaušanās un ekspansija ${ }^{15}$ sabiedriskajā apziņā un valsts varas aparātā (Ледяев 2002: 20). Viņa globālais virsmērķis ir visu iespējamo ietekmēšanas mehānismu pielietošana, lai izveidotu vienotu kristīgo politisko telpu, t. s. ǵeopolitisko diskursu, kurā „Evaņgēelijam jākḷ̂̄st par valsts likumdošanas pamatu, Evaņgẹēijam jākḷūst par tiem principiem, pēc kuriem dzīvos cilvēki visā pasaulē”. (Ледяев 2007) Bet par savu politisko uzdevumu A. Ļedjajevs uzskata dažādu kristiešu konfesiju un citu reliǵiju pārstāvju konsolidāciju cīṇai par kristiešu tiesību aizstāvēšanu, ${ }^{16}$ kas tāpat kopē labējo kristiešu stratēg̣iju veiksmīgai politikas īstenošanai.

Kādus mehānismus un ietekmes metodes izmanto kustība „Jaunā paaudze”, lai īstenotu šos mērķus un uzdevumus? Pirmkārt, jāpievērš uzmanība tam, ka A. Ļedjajevs spēj operatīvi nojaust un pielāgot savām interesēm sabiedrībā valdošu noskaņojumu, piemēram, attiecībā uz ES liberālajām idejām - vienlīdzīgās attieksmes ievērošana neatkarīgi no dzimuma, rases un etniskās piederības, reliǵiskās pārliecības vai seksuālās orientācijas. Izmantojot situāciju, kad lielākā sabiedrības dạ̧a nav gatava piln̄̄gi atzīt jaunās demokrātiski liberālās vērtības, kas balstītas uz vienlīdzības un dažādības principiem, A. Ļedjajevs aktīvi aǵitē cīnīties pret šīm vērtībām un to atbalstītājiem, visās pasaulēs nelaimēs vainojot seksuālās minoritātes, feministes, abortu aizstāvjus, islama reliğijas piekritējus.

Otrkārt, nozīmīga ir masu mediju loma sabiedrības atdzimšanas jeb ,jaunās pasaules kārtības” ieviešanas plānā. „Tas, kurš uzvarēs informācijas karā - tas uzvarēs atdzimšanā." (Ледяев 2002: 2) Moderno komunikāciju tehnolog̣iju pielietošana ir svarīgs instruments draudzes ,ietekmju zonu” un sabiedriskā diskursa konstruēšanai, piemēram, PR kampaņas [sabiedrisko attiecību kampaņas - D. K.] veidošana TV kanālos, radioprogrammās, internetā un presē. ${ }^{17}$ „Jaunā paaudze” pagaidām ne īpaši izvērsti, bet profesionāli izmanto šīs tehnologijijas, informējot savus piekritējus un pārējo sabiedrību par draudzes aktivitātēm un darbības rezultātiem.

\footnotetext{
15 Piemēram, leksēmas, kas raksturo kristīgās ideolog̣ijas pozicionēšanu, - „iebrukšana”, „ekspansija”, „,uzspiest”, , ,iznīcināt”, ,,dominēt”, ,ietekmēt”, ,valdīit”, ,,samīt”, ,,ienaidnieku spēki” u. c.

${ }^{16}$ Intervijā par pilsoņu pozīciju un kristiešu ekspansiju (otrā daḷā) A. Ļedjajevs atzīst: „,Saprotiet, kad es saku par jauno pasaules kārtību, es nerunāju par varas gāšanu, es nerunāju par revolūcijām - es runāju par savu pārstāvju izvirzī̌sanu valsts varas iestādēs, lai valstiskā līmen̄i viņi varētu aizsargāt Evaņgéelija intereses." (Ледяев 2002: 5)

${ }_{17}$ „Ja mēs runājam par garīgo atdzimšanu, tad tam nepieciešams PR [Public Relation - D. K.], nepieciešami masu mediji, jo lielākā daļa masu informācijas līdzekḷu ir angažēti, bet to masu informācijas līdzekḷu procents, kuri analizē jautājumus par garīgo atdzimšanu, diemžēl ir niecīgs.” (Cf. Aleksejs L,edjajevs (skatīts 08.03.2007.))
} 
Treškārt, atdzimšanai jānorit, aktīvi ietekmējot politisko eliti, piedāvājot tai konkrētas ideolog̣ijas modeli - ikviena sabiedrības locekḷa paḳ̣aušanu baznīcai. A. L̦edjajeva izpratnē šāds modelis nenovēršami būtu jāievēro visu valstu valdībām (Ледяев 2002: 23). P. Robertsona izteikumi un provizoriskie apgalvojumi par politiskās varas pakḷaušanos kristīgajai baznīcai ir visai līdzịgi: „Es gribu redzēt nākotni, kurā taisnīgie sabiedrības kalpi okupēs Balto namu un aizņems federālās pozīijas, vīrieši un sievietes vadīsies pēc pozitīvajiem principiem, godīguma un vienprātības." (Goldberg 2006) A. L̦edjajevs apzinās politiskās elites iesaistīšanas nepieciešamību savas ieceres īstenošanai, apgalvojot, ka tikai „no augšas”, no varas iestādēm - ministrijām, kongresiem un parlamentiem sabiedrības telpā jāienāk jaunās pasaules kārtības ideologijai (Ледяев 2002: 2-3).

Latvijā „Jaunās paaudze” cieši sadarbojas ar „mācītāju” politiskās partijas Latvijas Pirmās partijas (turpmāk - LPP) elites pārstāvjiem - Jāni Lujānu, Daini Turlaju, Aināru Šleseru, Jāni Šmitu, Aināru Baštiku, Intu Feldmani u. c. (Saulītis 2008). Presē un internetā bieži vien parādās ziņas par LPP biedriem, kuri pēc A. L̦edjajeva ielūguma apciemo „Jaunās paaudzes” rīkotos pasākumus (Cf. Латвийская (skatīts 13.02.2009.)). A. L̦edjajevs savukārt tiek aicināts uz LPP pasākumiem. Piemēram, 2007. gada novembrī Rīgā, Ineses Šleseres rīkotajās Lūgšanas brokastīs, starp citu kristīgo konfesiju pārstāvjiem un politiķiem bija arī A. L̦edjajevs (Левушкан 2007). No vienas puses, LPP biedri publiskajā telpā īpaši neuzsver savu saistību ar „Jauno paaudzi”, bet, no otras puses, pats A. L̦edjajevs un viņa organizācijas sabiedrisko attiecību aǵentūras darbinieki aktīvi popularizē savas „draudzīgās” un partneriskās attiecības ar atseviškiem partijas elites pārstāvjiem.

A. L̦edjajevs aktīvi meklē dialoga iespējas ar politisko varu arī ārpus Latvijas, par ko liecina viņa līdzdalība vairākās politiska rakstura aktivitātēs, pārsvarā ASV un Ukrainā. Šeit jāmin „Jaunās paaudzes” elites pārstāvju ārzemju vizītes, kas būtiski ietekmē šīs reliğiskās organizācijas attīstību un atpazīstamību pasaules publiskajā telpā. 2005. gadā „Jaunās paaudzes” līderi viesojās pie krist̄̄gās telekompānijas „God Digital” ǵenerāldirektora Rorija Aleka (Rory Alec), kopā ar Brūsu Andersonu (Bruce Anderson) viņi apciemoja ASV politisko „meku” - Vašingtonas Kapitoliju. Vizītes laikā notika tikšanās ar kristīgās telekompānijas CBN (Christian Broadcasting Network), Ridženta universitātes (Regent University) pārstāvjiem un P. Robertsonu, kā arī ar citām labējo kristiešu spārna autoritātēm, tostarp ar ASV valsts departamenta reliǵiju brīvības starptautiskās nodaḷas vadītāju. 
2006. gadā A. Ļedjajevs piedalās labējo kristiešu piketā pret atbalsta sniegšanu seksuālajām minoritātēm ASV Kalifornijas štata galvaspilsētā Sakramento. 2007. gada februārī viņš ir aicināts Nacionālajās Lūgšanu brokastīs (National Prayer Breakfast), ko iniciē toreizējais ASV prezidents Džordžs Bušs (Cihanoviča 2007), kurš ir A. L̦edjajeva politiskais favorīts, jo tieši Dž. Bušs sekmējis kristīgās ideoloǵijas principu nonākšanu ASV valdības dienas kārtībā (Ледяев 2002: 16). Atsaucoties uz faktu, ka Vašingtonā uz Lūgšanu brokastīm uzaicina viņu personīgi, A. L̦edjajevs aizstāv sevi pret pārmetumiem par viņa darbības ekstrēmisko un bīstamo raksturu (Avotiņš 2007).

A. Ļedjajeva izvērstās politiskās programmas ietekme ārpus Latvijas visvairāk novērojama Ukrainā. Viņa aktīvā līdzdalība un atbalsts 2004. gadā Ukrainā notikušajam politiskajam apvērsumam (Силенко 2006) nes pozit̄̄vus rezultātus, un jau 2008. gadā Ukrainā ir vairāk nekā 15 „Jaunās paaudzes” draudzes. Uzskatot A. Ľedjajevu par savu autoritāti, draudzes līderi aktīvi iesaistās kā sabiedriskajā, tā arī politiskajā dzīvē. Piemēram, reliǵiskajā organizācijā „Dieva vēstniecība”, kas atbalsta A. Ļedjajeva ,jaunās pasaules kārtības” ideju, piedalās daudzi valsts varas un politiskie līderi, ka arī pašvaldību vadītāji (Cf. Оранжевая победа 2008).

Organizācijai „Jaunā paaudze” ir vairāki starptautiska mēroga sadarbības partneri. Kopš 2005. gada „Jaunā paaudze” ir starptautiskās radikālās pretgeju kustības „Sargi uz mūriem” (The Watchmen on the Walls) dalībniece, un, kā apgalvots „Jaunās paaudzes” mājas lapā, A. L̦edjajevs ir viens no šīs kustības aktīvākajiem vadītājiem (Cf. Konference (skatīts 15.11.2007.)). Šì kustība bāzējas Sakramento ielejā, ASV, un ir ļoti populāra kristīgo fundamentālistu, it īpaši slāvu minoritātes pārstāvju vidū, kas izbraukuši no bijušās Padomju Savienības. ${ }^{18}$ Kustības oficiālajā mājas lapā atzīts, ka tā ir starptautiska kristiešu kustība par kristiešu cilvēktiesībām (Cf. Watchmen (skatīts 16.01.2009.)). Īpaši produktīvi A. L,edjajevs sadarbojas ar kustības „Sargi uz mūriem” dibinātajiem un aktīvistiem Skotu Laivliju (Scott Lively) un Kenu Hatčersonu (Ken Hutcherson), kuri ir kristiešu rekonstrukcionisma ideolog̣ijas propagandētāji un aktīvi cīnītāji pret seksuālajām

\footnotetext{
${ }^{18}$ Kustībā aktīvi darbojas grupa „Sargkareivji uz mūriem”, kura apvieno slāvu minoritāšu pārstāvjus pretgeju kampan̄ā. Organizācijas Southern Poverty Law Center ziņojumā rakstīts: „Amerikas rietumos Sargkareivji atraduši atbalstu krievvalodīgo fundamentālistu mācītāju vidū, kuri kādreiz dzīvojuši bijušajā Padomju Savienībā. [..] Sargkareivju kustības stratēgija cīṇā pret homoseksuālisma "slimību" aicina cilvēkus uz agresīvu konfrontāciju. [..] Nosaukums „Sargkareivji uz mūriem” nāk no Nechemijas grāmatas Vecajā derībā, kurā sargkareivji uzrauga iznīcinātās Jeruzalemes rekonstrukciju. Mūsdienu Sargkareivji apgalvo, ka viṇi aizsargā pilsētas, kuras iznīcina homoseksuālisms.” (Sančess 2007)
} 
minoritātēm. ${ }^{19}$ Latviju šajā kustībā pārstāv A. L̨edjajevs, organizācijas „No Pride” dalībnieks Igors Maslakovs un LPP biedrs Jānis Šmits.

Kustība „Sargi uz mūriem” tiecas īstenot kristiešu rekonstrukcionistu uzdevumu reformēt visas varas institūcijas vienā „kristīgajā valdībā”. Mērḳa sasniegšanai organizācija rīko masu konferences, demonstrācijas, piketus un citas politiskas akcijas, kuru laikā aicina „valsts iedzīvotājus aktīvi piedalīties svarīgākajos valsts politiskajos notikumos, piemēram, ASV prezidenta vēlēšanās un balsošanā par konstitūcijas labojumiem.” (Cf. Sargi uz mūriem (skatīts 06.11.2008)) 2008. gada oktobrī ASV notikušajā konferencē „Sargi uz mūriem” galveno uzsvaru liek tieši uz aktuālākajiem politiskajiem jautājumiem. Kā var spriest pēc „Jaunās paaudzes” mājas lapā publicētās informācijas par šo notikumu, referātu galvenā tēma ir ASV prezidenta vēlēšanas. Visi oratori aǵitē potenciālos vēlētājus atdot savas balsis par ,pareizajiem” kandidātiem, iestājoties pret tiem, kuri aizstāv sieviešu tiesības veikt abortus, atzīst homoseksuālās laulības un virza bīstamas sarunas ar islama līderiem. „Doktors Hatčersons izplata 350 tūkstošus DVD, kuros tiek atmaskota demokrātu kandidāta Baraka Obamas nostājas amoralitāte." (Cf. Sargi uz mūriem (skatīts 06.11.2008)) Līdzīgi rīkojas arī A. L̦edjajevs un citi „Jaunās paaudzes” līderi, iesaistoties priekšvēlēšanu kampaņā Latvijā. A. Ļedjajevs pats atzīst, ka draudze sastādījusi melno un balto politiķu sarakstu, melnajā sarakstā iekḷaujot tos politiķus, kuri atbalsta gejus.

Prezicionējot sevi kā kristīgo cilvēktiesību un gimenes vērtību patiesos aizstāvjus, „Jaunās paaudzes” komanda sabiedrības informatīvajā telpā pūlas radīt organizācijas censoṇa tēlu. 2006. gada 9. decembrī organizācija izplata „Rīgas deklarāciju par ticības brīvību, ğimenes vērtībām un cilvēktiesībām”, kurā atsaucas ne tikai uz Bībeli, bet arī uz starptautiskajiem cilvēktiesību dokumentiem. Jāpiemin organizācijas paziņojums laikrakstam „Diena” par reliğisko jūtu aizskārumu saistībā ar A. Ļedjajeva karikatūras publikāciju (Diena 30.01.2007.: 3), tā autori atsaucas uz starptautiskajām cilvēktiesību organizācijām un tiesībsargājošām iestādēm Amerikā (Rītdiena 24.02.2007.: 9). Zīmīgs ir arī paziņojums ministriju atbildīgajām amatpersonām, Latvijas Nacionālās radio un televīzijas padomes locekḷiem saistībā ar amatpersonu un vadītāju sodīšanu par „rupjiem un pārmērīgiem ētisko normu pārkāpumiem” televīzijas ēterā (Ледяев 2005). Šādos centienos piesaistīt sabiedrības uzman̄ibu var saskatīt kustības „Sargi uz mūriem” darbības stilu, kad, aktīvi iestājoties par kristiešu tiesību un gimenes vērtību aizsardzību ASV un citās valstīs, tiek izmantoti masu mediju instrumenti. Visticamāk „Jaunās paaudzes” līderi

\footnotetext{
${ }^{19}$ Piemēram, Skots Laivlijs, kurš ir viens no biežākajiem „Jaunās paaudzes” pasākumu viesiem, mudina neoharizmātus šādā veidā: „Ir sācies karš starp kristiešiem un homoseksuāḷiem. Ir jābūt modriem un jāatceras, kas seksuālās minoritātes nekad neapstāsies." (Nestere 2006: 4)
} 
pārņem šo praksi pēc vizītes ASV 2005. gadā, tās mērķis bija nostiprināt ciešākas saites ar labējo kristiešu spārna pārstāvjiem, tostarp arī ar kustību „Sargi uz mūriem” (Ледяев 2005).

Lai pievērstu sabiedrības uzmanību savām aktivitātēm, A. Ļedjajevs izmanto arī ietekmīgāko politisko figūru popularitāti. 2008. gadā presē publicētas A. Ļedjajeva uzslavas un cerīgās prognozes saistībā ar ministru prezidenta Ivara Godmaņa un valsts prezidenta Valda Zatlera darbību „kristīgās valsts” veidošanā un kristīgo pamatvērtību saglabāšanā (Cf. Zatlers un L̦edjajevs 2008). Augstākās varas pārstāvju neskaidrā pozīcija attiecībā uz „Jaunās paaudzes” darbību dod A. L̦edjajevam izdevību parādīties un pašizpausties publiskajā telpā.

A. Ľedjajevam adresētie politiķu izteikumi, uzrunas un apsveikumi, neoficiāli apstiprina viņa darbības atbalstu un norāda uz „Jaunās paaudzes” nozīmīgo lomu Latvijas sabiedriskās un politiskās apziņas veidošanā. ${ }^{20}$ Gan aicinājums piedalīties Nacionālajās Lūgšanu brokastīs ASV un Latvijā, gan atzinīgie vērtējumi no atsevišksu politiķu puses kḷūst par iemeslu kustības mērḳu un uzdevumu leg̣itimizācijai varas telpā (Avotiṇš 2007).

Tomēr ir gadījumi, kad valsts varas pārstāvji nav tik atsaucīgi „Jaunās paaudzes” piekoptās politikas atbalstītāji. Piemēram, bijusī Latvijas prezidente Vaira Vīḳe-Freiberga savā intervijā vācu laikrakstam „Jauno paaudzi” raksturo kā „vienu no krievu sektām”. (Радионов 2006)

A. L̦edjajevs mēǵina labējo kristiešu rekonstrukcionisma idejas ieviest publiskā diskursa telpā, izmantojot LPP politiskās varas atbalstu un labvēlību. Viņš nosauc LPP par kristiešu tiesību atbalstītājiem un politisko spēku, kas veidos Kristīgās Latvijas nākotni. ${ }^{21}$ „Jaunās paaudzes” politiskā atbalsta kampaņa satur vēlētāju balsu mobilizāciju, piekritēju politiskās līdzdalības intensificēšanu un konkrētas partijas interešu lobēšanu. Kā apgalvo

\footnotetext{
${ }^{20}$ Piemēram, Intas Feldmanes apsveikuma uzruna draudzei un tās vadītājam: ,Es jūs apsveicu ar to, ka šī konference ir kā Dieva Valstības gabalinş̌ latviešu zemē. Un, ja Dievs piemeklē kādu tautu, tad tajā notiek brīnumi. Lūk, arī Latvijas politiskajā dz̄ivē pagājušā gada decembrī notika brīnums: Ivara Godmaņa valdības deklarācijā bija rakstīts, ka Latvija ir kristīga valsts un ka tā attīstīsies, balstoties uz Dieva likumiem." (Saulīis 2008)

${ }^{21}$ Par šiem mēǵinājumiem liecina, piemēram, A. L̦edjajeva 2005. gada 18. maija uzstāšanās „Глава всякого начальства и власти” („Katras vadības un varas galva”) atreferējums draudzes locekḷiem par vizīti ASV: "Unikālā atdzimšanas pieredze Latvijā ir atklāsme par kristīgo valdību, un Pirmās partijas fenomens saviḷnoja cilvēku apziṇu un izsauca dz̄̄vu interesi. [..] Pie mums ir ḷoti nopietna Pirmā partija. Viṇiem ir obligāti jābūt uz lūgšanas brokastīm Vašingtonā. [..] Ja Dievs mūs „saderināja” ar Pirmo partiju, tad kur mēs liksimies brauksim kopā uz Vašingtonu. [..] P. Robertsons A. L̨edjajevam: „Jaunās paaudzes” un LPP sadarbība pārliecina mani, šie džeki sasnieguši nopietnus rezultātus. [..] A. Ľedjajevs P. Robertsonam: Un ja Jūs palīdzēsiet Pirmajai partijai, ja palīdzēsiet mums aizsargāt kristiešu vērtības labējā laukā, mēs būsim Jums visai pateicīgi." (Ледяев 2005)
} 
A. L̦edjajevs, draudzes locekḷi, pirmkārt, ir politisks spēks, aktīvi vēlētāji, kas politiskajā arēnā cīnās par kristiešu vērtībām un tiesībām.

\section{Secinājumi}

Rakstā tika aplūkota reliğiskās kustības „Jaunā paaudze” darbība un idejiskie koncepti, koncentrējot uzmanību uz tās politiskās līdzdalības veidiem un orientieriem. Tika identificēti kustības politiskās ideoloǵijas galvenie aspekti, kas nosaka tās politisko rīcību un attīstības vadlīnijas, kā arī sociālās un politiskās mobilitātes pakāpi. Tādi faktori kā komunikācijas tīklu veidošanā iesaistītie sociālie aǵenti, diskursīvas telpas konstruēšanai izmantojamā izteiksmes retorika un tās saturs, stratēǵiskās attīstības plānošanas modeḷi un politiskie lozungi ļauj identificēt „Jauno paaudzi” kā uz krist̄̄go fundamentālismu orientētu reliğisku kustību, kas savu ideolog̣iju konstruē pēc labējo kristiešu politiskajām tehnolog̣ijām un rīcības modeļiem. Organizācijas īstenotā politiskā ideologija satur kristiešu rekonstrukcionisma programmas un stratēg̣ijas pazīmes. Šajā ziņā „Jaunā paaudze" ir viena no organizācijām, kas piekopj visai agresīvu un mērḳtiecīgu politisku darbību. Apgalvojums, ka organizācija ir pārṇēmusi ASV labējo kristiešu fundamentālistu ideologiju, izskatās racionāls, ņemot vērā tās centienus paplašināt savus sociālās komunikācijas tîklus, apgūt politisko un sabiedrisko telpu un apzināt savu vietu tajā.

\section{LITERATŪRAS SARAKSTS}

Aleksejs L̦edjajevs atklāj Ukrainas turneju ar dievkalpojumu Kijevā. (21.01.2009.).

http://www.newgeneration.lv/lat/zinas/reportazas_no_izbraucieniem/?doc=7514.

Aleksejs L̦edjajevs: par atdzimšanu, kristīgām vērtībā̄m un PSRS-2. (08.03.2007.).

http://www.ng.lv/lat/zinas/arhivs/?doc=1074.

Anderson, A. (2004). An Introduction to Pentecostalism: Global Charismatic Christianity.

Cambridge: Cambridge University Press.

Avotiņš, V. (09.11.2007). Sarūmējieties, baznīckungi! Neatkarīgā Rīta Avīze.

Barker, E. (2001). New religious movements. The International Encyclopedia of the Social and Behavioral

Sciences. Elsevier Science: Pergamon, Amsterdam, pp. 10631-10634.

Baznīca. http://www.newgeneration.lv/lat/baznica/. (Skatīts 15.12.2008.)

Baznīcas terminu vārdnīca. http://www.eleison.lv/vardnica/terminu/s.htm. (Skatīts 16.01.2009.)

Berger, P. (1969). Social Reality of Religion. London: Faber.

Christian Colaition of America. http://www.cc.org/. (Skatīts 04.03.2009.)

Chryssides, G. D. (1997). New Religious Movements: Some Problems of Definition. Internet Journal of

Religion. http://web.uni-marburg.de/religionswissenschaft/journal/diskus/chryssides.html.

Clarkson, F. (1994). Christian Reconstructionism. Public Eye Magazine, 1994.-March / June.

http://www.publiceye.org/magazine/v08n1/chrisrec.html

Coleman, S. (2000). The Globalisation of Charismatic Christianity. Cambridge: Cambridge University Press.

Cihanoviča, J. (2007). Vara, sekss un brokastis. Sabiedriskās politikas portāls politika.lv.

http://www.politika.lv/index.php?id=14855.

Dzērve, L. (2007). Valdis Zatlers tiek pie draudzes Jaunā paaudze simpātijām.

http://www.diena.lv/lat/arhivs/latvijas-zinas/valdis-zatlers-tiek-pie-draudzes-jauna-paaudze-simpatijam.

Encyclopaedia Britannica. http://www.britannica.com/EBchecked/topic/391738/Moral-Majority. (Skatits 16.01.2009.)

Goldberg, M. (2006). Kingdom Coming: The Rise of Christian Nationalism. $1^{\text {st }}$ ed. W. W. Norton \& Company. 
Grāmatas. http://www.newgeneration.lv/lat/svetrunas_gramatas_skola/. (Skatīts 15.12.2008.)

Hicks, J. (1996-2003). The Political Subsistence of the Religious Right: why the Christian Right Survives and Does not Thrive. The American Religious Experience. http://are.as.wvu.edu/jhicks.html.

„,Jaunā paaudze” izmanto Zatlera vārdu savu ideju popularizēšanai. (28.05.2008.).

http://www.delfi.lv/news/national/politics/article.php?id=21062072.

„Jaunās paaudzes” līderis nikns uz valdību. (25.05.2007.). http://news.frut.lv/lv/ppl/society/2603.

Konference "Sargi uz mūriem". Otrā diena. (15.11.2007.).

$\mathrm{http}: / /$ www.newgeneration.lv/lat/zinas/watchmen_on_the_walls/?doc=3556 .

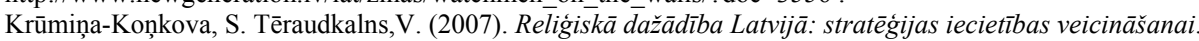
Rīga: Îpašu uzdevumu ministra sabiedrības integrācijas lietās sekretariāts.

Latvijas Religiskās organizācijas (2005). Rīga: Agneta T.

Linker, D. (2008). Sticking With the Devil They Know.The New Republic. A Journal of Politics and the Arts.

http://blogs.tnr.com/tnr/blogs/linker/archive/2008/11/07/sticking-with-the-devil-they-know.aspx.

LPP slavināšana kḷuvusi par galveno „Jaunās paaudzes” sludinājumu sastāvdalu.u. (20.09.2006.).

http://www.apollo.lv/portal/news/72/articles/83049.

Mēs esam unikāli. (2005). Tikšanās. Nr.1. 4-8.

http://www.tiksanas.lv/index.php?option=com_content\&view=article\&id=39\&Itemid=3.

Murray, O. D. (1996). The Right and the Righteous: The Christian Right Confronts the Republican Party.

Lanham: Rowman \& Littlefield.

The Moral Majority Coalition. http://www.moralmajority.com/ . (Skatīts 16.01.2009.)

Nestere, L. (08.07.2006.). Aicina būt modriem saistībā ar homoseksuāḷu aktivitātēm. Neatkarīgā Rìta Avīze.

New Generation Christian Center. Territory of New Generation.

http://www.ngteam.org/english/territory.htm. (Skatīts 16.01.2009.)

Prasa atvainoties kristiešiem. (30.01.2007.). Diena.

Protestantu baznīcas "Jaunā Paaudze" pazinojums. (25.06.2007.) http://news.frut.lv/lv/polit/politics/5179.

Publiska atvainošanās vēl nav saņemta. (24.02.2007.). Rītdiena.

Reliğisko lietu pārvaldes 2007. gada pārskats. (2008).

http://www.tm.gov.lv/lv/ministrija/imateriali/parskati/2007.html.

Reliǵisko savienību (baznīcu), diecēžu un reliğisko organizāciju 2008. gadā pārskats. (2009).

http://www.tm.gov.lv/lv/documents/parskati/2008/rel org parskats 2008.doc.

Prayer Breakfas Network. http://pbnet.org/. (Skatīts 16.01.2009.)

Robertson, P. (1991). The New World Order. Dallas: World publishing.

Sančess, Keisijs (20.11.2007.). Saikne ar Latviju. Southern Poverty Law Center zinojums.

http://www.politika.lv/print.php?id=14858.

„Sargi uz mūriem”. Amerikas turneja. (06.11.2008.).

http://www.newgeneration.lv/lat/zinas/watchmen_on_the_walls/?doc $=6746$.

Saulītis, A. (07.07.2008.). Šlesers uzrunā "Jauno paaudzi"”.

http://jauna.diena.lv/lat/politics/politika/slesers-uzruna-jauno-paaudzi.

Stark, R. \& Bainbridge, W.S. (1985). Of Churches, Sects and Cults. The Future of Religion: Secularization and Cult Formation. Berkley e.a.

Tēraudkalns, V. (2007). Draudze «Jaunā paaudze» — sekta vai baznīca? Ceļojums ar citādo: subkultūras pilsētas vidè. Rīga: Dialogi.lv.

The Official Site of Pat Robertson. www.patrobertson.com. (Skatits 16.01.2009.)

Watchmen on the Walls - International Christian Movement for Human Rights.

http://www.watchmenonthewalls.com/. (Skatits 16.01.2009.)

Wilcox, C. (1996). Onward Christian Soldiers? The Religious Right in American Politics. Bolder: Westview Press.

Wilkey, D. (1991). New World Order by Pat Robertson. A Christian looks at the Religious Right.

http://www.livingston.net/wilkyjr/link26.htm.

Zatlers un L̦edjajevs vienojas kopīgā lūgšanā. (08.11.2008.). http://www.postfactum.lv/1/1/?id_news=26317. Бог увидит, за кого вы проголосуете.

http://www.pctvl.lv/?lang=ru\&mode=rakurs\&submode=wrotelat\&page_id=4355. (Skatīts 21.01.2009.)

Гаджиев, К.С. (1999). Введение в политическую науку. Москва: Логос.

Иоффе, Г. (2005). Христианское осмысление проблемы наркомании. Наркотики и религия. Журнал

„Санкт-Петербургский университет”. № 3. http://www.spbumag.nw.ru/2006/02s/3.shtml.

Латвийская ,, партия священников" и „,Новый мировой порядок”.

http://www.kompromat.lv/item.php?docid=readn\&id=2147. (Skatīts 13.02.2009.)

Левушкан, П. (2007). Алексей Ледяев: Христиане имеют право участвовать в политической жизни. http://www.baznica.info/pagesid-4575.html.

Ледяев, А. (2002). Новый мировой порядок. Рига: Новое Поколение. 


\section{RAKSTI}

Ледяев, А. (2005). Глава всякого начальства и власти.

http://www.komardin.ru/files/060421022644.rar?PHPSESSID=ba2c9417ccea1b42b2cc018c41f7ae12.

Ледяев, А. (2007) Гражданская позиция и христианская экспансия 2. (28.04.2007.)

http://www.newgeneration.lv/rus/dla_pressi/interv_u_pastora/in_site/in_site/tools/transfer.php?file=files/text/ 042807-2_int_messian_pdf.pdf.

Ледяев рассказывает о своих школьных годах, знакомстве с женой Ольгой, о том, как мирится с ней и о Ленине. (16.02.2006.). http://prochurch.info/index.php/more/4162.

Мейден, И. (2008). , Моя „,крышиа” - Христос!” http://www.ves.lv/article/57049.

Михайлов, С. Ледяев и лидеры Латвийской первой партии отправились в Вашингтон помолиться.

http://www.kompromat.lv/item.php?docid=readn\&id=2163. (Skatīts 10.12.2008.)

„Новое поколение” в Украине стала конфессией. (06.03.2007.).

http://news.invictory.org/issue $10722 . \mathrm{html}$.

„Оранжевая победа" латвийских сектантов.

http://www.kompromat.lv/item.php?docid=readn\&id=1219. (Skatīts 10.12.2008.)

Официальная позиция "Слова Жизни" по Новому Мировому Порядку от НП. (2004).

http://jesuschrist.ru/forum/showthreaded.php?Cat=\&Board=\&Number=139828.

Пугачев, В., Соловьев, А. (2000). Введение в политологию. Москва: Аспект Пресс.

Радионов, В. (2006). Президент: „Против геев выступили религиозные круги и одна русская секта.” (28.07.2006.). http://www.interfax-religion.ru/latvia/?act=print\&div=4038.

Рижская Декларация о Свободе Вероисповедания, Семейных Ценностях и Правах Человека. (2006). http://www.baznica.info/index.php?name=Pages\&op=page\&pid=2929.

Сектант Ледяев устанавливает Новый мировой порядок в Украине?

http://www.kompromat.lv/item.php?docid=readn\&id=1214_. (Skatīts 10.12.2008.)

Философский словарь. (2001). Москва: Республика.

Шабанов, А. (05.01.1995.). Опасные игры от имени Христа. Диена.

Шлесерс выступил на конференции „Нового поколения”. (07.07.2008.).

http://rus.delfi.lv/news/daily/politics/article.php?id=21337577\&categoryID=18698009. 